ks. Henryk Sławiński ${ }^{1}$

Uniwersytet Papieski Jana Pawła II w Krakowie

\title{
Problem
}

\section{wykluczenia społecznego w kościelnej posłudze słowa}

Autor sześciotomowej biografii Abrahama Lincolna, Carl August Sandburg (1878-1967), pytany o opinię na temat najbrzydszego słowa w języku angielskim, odpowiedział, że jest nim „ekskluzywność”. Przymiotnik odsłowny „ekskluzywny” ma podwójne znaczenie: „luksusowy”, ale też „elitarny”, „odgrodzony od ogółu”, „zastrzeżony dla zamkniętej grupy”. O ile „ekskluzywizm” charakteryzuje sekty, o tyle cechą Kościoła jest jego powszechność, „katolicyzm”. „Katolickość” w swym greckim źródłosłowie oznacza „powszechność", która jest cechą prawdziwego i niepodzielonego Kościoła: obejmuje on w jeden Lud Boży

1 Ks. Henryk Sławiński - dr hab., homileta i pedagog, profesor Uniwersytetu Papieskiego Jana Pawła II w Krakowie. Wykładowca homiletyki w Wyższym Seminarium Duchownym w Tarnowie, w Wyższym Seminarium Duchownym Księży Misjonarzy św. Rodziny. Redaktor naczelny czasopisma teologicznego „Polonia Sacra”; przewodniczący Stowarzyszenia Homiletów Polskich, członek międzynarodowego stowarzyszenia Fides et ratio, członek Komisji Języka Religijnego PAN, członek Polskiego Towarzystwa Teologicznego. Mieszka w Krakowie. E-mail: henryk.slawinski@upjp2.edu.pl.

2 Por. R. P. Waznak, An Introduction to the Homily, Collegeville, MN 1998, s. 128-129; K. E. Anderson, J. J. Bacik, A Light Unto My Path. Crafting Effective Homilies, New York-Mahwah, NJ 2006, s. 121-122. 
ludzi różnych ras, języków i kultur³. Dobra Nowina Jezusa Chrystusa, założyciela Kościoła dotyczy zbawienia wszystkich ludzi. Nie oznacza to, że wszyscy muszą przyjąć Dobrą Nowinę. Kościół odrzuca prozelityzm. O ile w przeszłości prozelityzm traktowano często jako synonim ewangelizacji, zaangażowania na rzecz zdobywania konwertytów, o tyle od czasu soboru watykańskiego II termin ten ma niemal zawsze znaczenie pejoratywne i oznacza „zmuszanie ludzi lub manipulowanie nimi tak, żeby przyjęli taką, a nie inną wiarę" ${ }^{4}$. Wspomniany sobór potępiał tak rozumiany prozelityzm; podkreślając prawo każdej osoby do wolności sumienia i wyznania ${ }^{5}$. Tak więc Kościół nie włącza do swojego grona na siłę kogoś, kto sobie tego nie życzy. Z drugiej strony Kościół ma prawo stawiać wymagania swoim członkom. Niespełnienie niektórych istotnych wymogów sprawia, że człowiek wyklucza się bądź zostaje wykluczony nie tyle ze wspólnoty Kościoła, ile z przyjmowania sakramentów i korzystania z pełni praw w Kościele. Łaciński termin określający wyłączenie z przyjmowania sakramentów i korzystania z pełni praw w Kościele to „ekskomunika”. Jest ona rozumiana, jak wszystkie kary w Kościele, jako środek leczniczy służący temu, by człowiek uświadomił sobie nieuporządkowane sprawy w swoim życiu.

W niniejszym opracowaniu nie chodzi o wykluczenie ze wspólnoty duchowej, ale raczej o wykluczenie społeczne. Jest to stosunkowo nowe zjawisko, które zostało zidentyfikowane we współczesnym świecie. Celem niniejszego opracowania jest omówienie problemu wykluczenia w kościelnej posłudze słowa. Najpierw zwrócimy uwagę na kwestię wykluczenia w kontekście nowej wrażliwości Kościoła. Następnie podkreślimy uniwersalizm orędzia Chrystusa, który wyklucza „wykluczenie świadome”. Kolejnym etapem będzie omówienie problemu „wykluczenia

3 Por. Sobór Watykański II, konst. Lumen gentium, 13; G. O’Collins, E. G. Farrugia, Leksykon pojęć teologicznych i kościelnych z indeksem angielsko-polskim, przekł. J. Ożóg, B. Żak, Kraków 2002, s. 72.

${ }^{4}$ G. O'Collins, E. G. Farrugia, Leksykon pojęć teologicznych i kościelnych..., dz. cyt., s. 144.

5 Sobór Watykański II, dekret Ad gentes divnitus, 13; Sobór Watykański II, dekret Dignitatis humanae, 4.

6 G. O'Collins, E. G. Farrugia, Leksykon pojęć teologicznych i kościelnych..., dz. cyt., s. 41; Kodeks prawa kanonicznego, Poznań 1983, kan. 1331. 
nieświadomego". Odpowiedzią na wskazane problemy będzie podkreślenie potrzeby głoszenia osoby i orędzia Jezusa, który utożsamił się z wykluczonymi. Na koniec refleksji podamy przykład kształtowania wyobraźni miłosierdzia w posłudze Mistrza z Nazaretu, Jego pedagogię, która przemienia społeczeństwo od wewnątrz tak, że jego członkowie rezygnują z wykluczania na rzecz integracji wykluczonych.

\section{Wykluczeni - nowa wrażliwość Kościoła}

Kim są ,wykluczeni”? Sam termin ,wykluczeni” jest nowy w nomenklaturze kościelnej. Wcześniej nie był stosowany. Przegląd Leksykonu teologii pastoralnej (Lublin 2006) ${ }^{7}$ prowadzi do konstatacji, że brakuje w nim osobnego terminu „wykluczeni”. Brak go także w XX tomie Encyklopedii katolickiej. ${ }^{8}$. Według ,Słownika języka polskiego termin „wykluczony" to imiesłów przymiotnikowy bierny pochodzący od czasownika „wykluczyć”, znaczącego także „,usunąć", ,wyłączyć”, ,,wyeliminować”. Termin ten został obecnie na dobre wprowadzony do terminologii pastoralnoteologicznej.

Podczas rekolekcji głoszonych w dniach 12-18 marca 2000 roku w Watykanie dla papieża i Kurii Rzymskiej wietnamski arcybiskup Francis Xavier Nguyen Van Thuan (1928-) mówił, że jeśli nie dokona się przemiana serc, znaczna część ludzkości będzie zagrożona ryzykiem przejścia od doświadczenia wykorzystania do wykluczenia, a od wykluczenia do eliminacji - być może nawet fizycznej ${ }^{10}$. To były niemal profetyczne

Leksykon teologii pastoralnej, red. R. Kamiński, W. Przygoda, M. Fiałkowski, Lublin 2006.

8 Encyklopedia katolicka, t. 20, red. E. Gigilewicz, Lublin 2014. To samo trzeba powiedzieć o Encyklopedii nauczania społecznego Jana Pawła II, red. A. Zwoliński, Radom 2003. Wśród wielu haseł nie ma hasła „wykluczeni”. W książce Kennetha R. Himesa OFM, Odpowiedzi na 101 pytań o katolicka naukę społeczną (Kraków 2005, s. 60-61) znajdziemy wyjaśnienie preferencyjnej opcji na rzecz ubogich, ale o wykluczeniu społecznym autor nie wspomina.

9 Słownikjęzyka polskiego, t. 3, red. H. Szkiłądź i in., Warszawa 1985, s. 806.

10 „Without a conversion of heart, a good part of humanity risks passing from the experience of exploitation to exclusion, and from exclusion to true and proper elimination perhaps even physical" - F. X. Nguyen Van Thuan, Testimony of Hope. The Spiritual Exercises of John Paul II, Boston 2000, s. 38. 
słowa, których echem jest kilka wypowiedzi papieża Franciszka. Papież z Argentyny w alarmujący sposób upomina się o poprawę sytuacji ludzi wykluczonych.

Za sprawą papieża Franciszka termin „wykluczeni” został spopularyzowany w społecznym nauczaniu Kościoła jako termin opisujący bardzo negatywne zjawisko charakteryzujące zglobalizowany świat w naszych czasach. Poprzednicy Franciszka dostrzegali inne problemy albo nazywali analogiczny problem innymi sformułowaniami. Na przykład Jan Paweł II nie pisał jeszcze w swoich encyklikach społecznych o osobach wykluczonych. Wprowadził natomiast pojęcie „czwartego świata”. W encyklice Sollicitudo rei socialis (30.12.1987) Jan Paweł II przypomniał encyklikę Pawła VI Populorum progressio (26.05.1967), która przewidywała, że niesprawiedliwe systemy społeczne będą powodowały powiększanie bogactwa bogatych, przy równoczesnym utrwalaniu i pogłębianiu nędzy ubogich. Od siebie zaś Jan Paweł II dodał: „Potwierdzeniem tego przewidywania jest pojawienie się tak zwanego C zwartego Świata"11. Co ten termin oznacza? Wyraża on fakt, że społeczeństwa światowe są niejednolite. Pierwszy świat oznacza społeczeństwa zamożne. Drugi społeczeństwa na drodze rozwoju, a więc pośrednie między drugim i trzecim światem. Trzeci świat oznacza kraje biedne. Termin „czwarty świat” natomiast służy określeniu obszarów wielkiej nędzy w krajach dobrze rozwiniętych ${ }^{12}$. Papież uświadomił światu, że również w niektórych społeczeństwach bardzo zamożnych u drzwi bogaczy leżą lekceważeni Łazarze.

Jeszcze za pontyfikatu polskiego papieża Papieska Rada Iustitia et Pax posłużyła się terminem „wykluczenia społecznego” w Kompendium nauki społecznej Kościoła (Cittá del Vaticano 2004). Niestety forma przekazu tego kompendium nie jest prosta, a przez to za mało komunikatywna.

W numerze 171 Kompendium nauki społecznej Kościoła Papieska Rada Iustitia et Pax wspaniale opisuje Boży plan dla ludzkości i świata: „Bóg dał ziemię całemu rodzajowi ludzkiemu, aby utrzymywała wszystkich jego

11 Jan Paweł II, enc. Sollicitudo rei socialis, 16.

12 Jan Paweł II, enc. Sollicitudo rei socialis, 17. 
członków, nie wykluczając ani nie wyróżniając nikogo"13. Natomiast w dwóch innych miejscach (nr 174,308), mówiąc o wykluczeniu społecznym, dokument ten gubi wielkość problemu w rozwleczonych, zawoalowanych sformułowaniach, które tracą siłę przekonania, a w związku z tym pozostają bez echa:

„Zasada powszechnego przeznaczenia dóbr zachęca do popierania wizji ekonomii opartej na wartościach moralnych, które nie pozwolą nigdy na utracenie z pola widzenia źródła ani celu tych dóbr, tak by można było budować świat sprawiedliwy i solidarny, gdzie powstawanie bogactwa mogłoby spełniać pozytywną funkcję. Rzeczywiście, w wielości form mogących je wyrażać bogactwo stanowi tę wartość, która jest rezultatem wydajnego procesu techniczno-ekonomicznego, wykorzystującego dostępne zasoby, naturalne i przetworzone, dokonującego się dzięki inwencji, umiejętności planowania i pracy ludzi, który może być używany jako pożyteczny środek wspierający dobrobyt ludzi i narodów, a także sprzeciwiający się ich wy kluc zaniu oraz wyzyskowi"14.

Drugi fragment podejmujący kwestię wykluczenia społecznego jest nie mniej zawoalowany. Wymienia jeden tylko powód wykluczenia, który jest konsekwencją braku kwalifikacji zawodowych:

„Współczesna sytuacja społeczno-ekonomiczna, charakteryzująca się coraz szybciej zachodzącymi procesami globalizacji gospodarczo-finansowej, zmusza związki zawodowe do odnowy. Dzisiaj związki zawodowe wezwane są do nowych form działalności i poszerzania zakresu swojego solidarnego działania w taki sposób, by ochraniać poza tradycyjnymi kategoriami także tych pracowników, którzy pracują na podstawie nietypowych kontraktów albo umów na czas określony; tych, których posada jest zagrożona ze względu na coraz częściej występujące, również na poziomie międzynarodowym, fuzje przedsiębiorstw; ludzi pozbawionych pracy, emigrantów, pracowników sezonowych, tych, którzy zostali wykluczeni z rynku pracy z powodu braku dodatkowych kwalifikacji

13 Papieska Rada Iustitia et Pax, Kompendium nauki społecznej Kościoła (Cittá del Vaticano 2004), przekł. D. Chodyniecki, A. Dalach, J. Nowak, Kielce 2005, nr 171.

14 Papieska Rada Iustitia et Pax, Kompendium nauki społecznej Kościoła, dz. cyt., nr 174. 
zawodowych i nie mogą na ten rynek powrócić bez odpowiednich kursów umożliwiających im przekwalifikowanie się"15.

Jakkolwiek termin „wykluczenie społeczne” został wprowadzony do słownictwa społecznego nauczania Kościoła za Jana Pawła II, to dopiero Franciszek spopularyzował go na dobre, dzięki temu, że zastosował język lakoniczny, obrazowy i egzystencjalny, czyli odwołujący się do doświadczenia życiowego. Ponadto zwrócił uwagę na wykluczenie nie tylko z jakiejś grupy społecznej, ale w ogóle ze społeczeństwa. Pisząc w adhortacji Evangelii gaudium (24.11.2013) na temat kryzysu zaangażowania wspólnotowego oraz niektórych wyzwań współczesnego świata, Franciszek ogłosił swój manifest - litanię sprzeciwu społecznego: „Nie” dla ekonomii wykluczenia. „Nie” dla nowego bałwochwalstwa pieniądza. „Nie” dla pieniądza, który rządzi, zamiast służyć. „Nie” dla nierówności społecznej rodzącej przemoc. Każdą z tych kwestii Franciszek rozwinął. Wyrażając swój zdecydowany sprzeciw wobec „ekonomii wykluczenia”, Franciszek skonstatował: „Samego człowieka uważa się za dobro konsumpcyjne, którego można użyć, a potem je wyrzucić. Daliśmy początek kulturze «odrzucenia», którą wprost się promuje. Nie chodzi już po prostu o zjawisko wyzysku i ucisku, ale o coś nowego: przez wykluczenie dotyka się samego korzenia przynależności do społeczeństwa, w którym człowiek żyje, jako że nie jest w nim na samym dole, na peryferiach, lub bez władzy, ale jest poza nim. Wykluczeni nie są «wyzyskiwani», ale są odrzuceni, są «niepotrzebnymi resztkami» (leftovers)"16.

Kilka miesięcy przed publikacją adhortacji Evangelii gaudium, 5 czerwca 2013 roku Franciszek wygłosił wstrząsające, obrazowe przemówienie podczas audiencji ogólnej na temat pilnie potrzebnej ekologii. Upomniał się o wykluczonych traktowanych jak nieużyteczne odpady:

„A Bóg, nasz Ojciec powierzył zadanie strzeżenia ziemi nie pieniądzom, ale nam, mężczyznom i kobietom. My mamy to zadanie! W ten sposób kobiety i mężczyźni są poświęcani bożkom zysku i konsumpcji: jest to «kultura odrzucania». Jeśli psuje się komputer, to mamy

15 Papieska Rada Iustitia et Pax, Kompendium nauki społecznej Kościoła, dz. cyt., nr 308.

16 Franciszek, adhort. apost. Evangelii gaudium, 53. 
do czynienia z tragedią, ale ubóstwo, potrzeby, dramaty wielu osób stają się ostatecznie normalnością. Jeśli pewnej zimowej nocy tutaj w pobliżu na Via Ottaviano umrze jakiś człowiek, to nie jest to wielką wiadomością. Jeśli w tak wielu miejscach świata są dzieci, które nie mają co jeść, to nie jest to wielką wiadomością, wydaje się to czymś normalnym. Tak być nie może! A takie rzeczy stają się normalnością. Natomiast spadek na giełdach niektórych miast o 10 punktów stanowi tragedię. Umierający - to nie jest wiadomość, ale spadek na giełdach o 10 punktów staje się tragedią. W ten sposób osoby zostają «odrzucone», odrzucamy ludzi, tak jakby byli odpadami ${ }^{17 "}$.

Takie sformułowania wywołały echo społeczne. Poruszona została wrażliwość na los pojedynczego człowieka, który przestał się liczyć w globalnym świecie interesów i multimedialnych połączeń.

Miłość do ludzi ubogich, dziś można mówić: do wykluczonych, należy, jak tego uczy papież Franciszek, uznać za preferencyjną opcję w przepowiadaniu i duszpasterstwie Kościoła. Biskupi uczestniczący w XII zwyczajnym synodzie w Rzymie w 2008 roku na temat słowa Bożego w życiu i misji Kościoła podkreślali, że przepowiadanie słowa Bożego powinno odznaczać się preferencyjną opcją na rzecz ubogich: „Istotnie, «w pierwszej kolejności mają prawo do orędzia Ewangelii właśnie ubodzy, potrzebujący nie tylko chleba, ale również Słowa życia»" ${ }^{18}$. Głosiciele homilii powinni wsłuchiwać się w głos ubogich, uczyć się od nich, towarzyszyć im w wierze oraz zachęcać do twórczego przeżywania życia ${ }^{19}$, a także wskazywać na potrzebę poszukiwania złotego środka, jakim jest

17 Franciszek, Audiencja ogólna. Pilnie potrzebna ekologia (05.06.2013), http://info.wiara. $\mathrm{pl} /$ doc/1584356.Pilnie-potrzebna-ekologia (27.04.2018). Zob. Papiez: Zepsuty komputer - tragedia. Dramat osób - normalność, http://info.wiara.pl/doc/1584238.Papiez-Zepsuty-komputertragedia-Dramat-osob-normalnosc (27.04.2018); por. J. Dziedzic, Kościół wobec starości. Perspektywa pastoralnoteologiczna, „Polonia Sacra” 19 (2015) nr 1 (38), s. 97.

18 XII Zwyczajne Zgromadzenie Ogólne Synodu Biskupów, Propositio 11; cyt. za: Benedykt XVI, ahort. apost. Verbum Domini, 107; por. H. Sławiński, Troska Kościoła o poprawę jakości homilii: od synodu o Eucharystii i Sacramentum Caritatis do synodu o słowie Bożym $i$ Verbum Domini, „Colloquia Theologica Ottoniana” 1 (2012), s. 37-62.

19 Por. Benedykt XVI, Verbum Domini, 107; H. Sławiński, Preferencyjna miłość do ubogich w przepowiadaniu Kościoła, „Analecta Cracoviensia” 49 (2017), s. 171. 
równowaga „między ubóstwem, «które należy wybrać», i ubóstwem, «które trzeba zwalczać»"20.

Papież Franciszek potwierdził i jeszcze bardziej wzmocnił preferencyjną opcję Kościoła na rzecz ubogich w przepowiadaniu. Zarządził bowiem, aby co roku w trzydziestą trzecią niedzielę zwykłą roku liturgicznego obchodzony był „Światowy Dzień Ubogich”. W przygotowanym przez siebie Orędziu na I Światowy Dzień Ubogich obchodzony 19 listopada 2017 roku Franciszek wyeksponował przekonanie, że dzięki ubogim można lepiej zrozumieć orędzie Chrystusa: „dzielenie się z biednymi pozwala nam zrozumieć Ewangelię w najgłębszej jej prawdzie. Biedni nie są problemem, ale zasobem, z którego możemy zaczerpnąć, aby przyjąć i żyć istotą Ewangelii" ${ }^{21}$.

Troska o ludzi ubogich i wykluczonych należy do zwyczajnych zadań biskupów. Organizowane przez nich dzieła charytatywne nie powinny nigdy sprowadzać się do zwykłej filantropii, ale raczej stanowić okazję do usłyszenia słowa Bożego i do nawrócenia serca ${ }^{22}$.

\section{Uniwersalizm orędzia Chrystusa wyklucza „wykluczenie świadome"}

Orędzie Chrystusa proklamowane przez Kościół wyklucza „świadome wykluczenie" kogokolwiek spośród adresatów Dobrej Nowiny o zbawieniu. Nie ma na to miejsca w doktrynie Kościoła. Przeciwnie, Kościół podkreśla, że „Bóg pragnie, by wszyscy ludzie zostali zbawieni” (por. 1 Tm 2, 4). Orędzie zbawienia proklamowane przez Kościół ma charakter uniwersalny. Odpowiednio też urzędowi przedstawiciele Kościoła - kapłani są „sługami Ewangelii Chrystusa w stosunku do wszystkich ludzi”23.

20 Por. Benedykt XVI, adhort. apost. Verbum Domini, 107.

${ }^{21}$ Franciszek, Orędzie na I Światowy Dzień Ubogich (33 niedziela zwykła w ciągu roku), 19 listopada 2017. Nie miłujmy słowem, ale czynem (13.06.2017), 9.

22 Por. Kongregacja ds. Biskupów, Dyrektorium o pasterskiej posłudze biskupów Apostolorum Successores (22 lutego 2004), 196.

${ }^{23}$ Kongregacja Kultu Bożego i Dyscypliny Sakramentów, Nowe ogólne wprowadzenie do Mszału rzymskiego. Z trzeciego wydania Mszału rzymskiego (18.03.2002), Poznań 2004, nr 385. 
W ostatnich latach podkreśla się nawet, że istnieje nadzieja zbawienia dla ludzi nieochrzczonych, w tym dla dzieci zmarłych bez chrztu ${ }^{24}$. Albowiem Bóg, który pragnie zbawienia wszystkich ludzi, związał wprawdzie „zbawienie z sakramentem chrztu, ale sam nie jest związany swoimi sakramentami"25.

W modlitwie liturgicznej w Wielki Piątek, która jest wyrazem wiary Kościoła, zgodnie z adagium lex credendi legem statuat suplicandi, Kościół ogarnia modlitwą wszystkich ludzi. Ten powszechny dar zbawienia zawdzięczamy Chrystusowi. Jego śmierć za wszystkich i zbawienie dokonane przez Niego obiektywnie dla wszystkich jest, co warto dodać, dostępne dla ludzi w Kościele, który jest konieczny do zbawienia ${ }^{26}$. Jak podkreśla soborowa konstytucja Lumen gentium, Kościół jest „powszechnym sakramentem zbawienia" (por. KK 1; 48). Podobnie, choć za pomocą innych słów, dokument Kongregacji Nauki Wiary Dominus Iesus stwierdza, że Kościół jest „narzędziem zbawienia całej ludzkości (por. Dz 17, 30-31)”27 i „w planie Bożym ma nieodzowny związek ze zbawieniem każdego człowieka"28. Dar zbawienia udzielany przez Boga ma związek z Kościołem ${ }^{29}$, nawet względem osób, które nie zostały do niego włączone przez wiarę i chrzest święty.

Komentując pierwsze słowa Modlitwy Pańskiej, Katechizm Kościoła katolickiego podkreśla uniwersalizm chrześcijaństwa. Gdy odmawiamy modlitwę Ojcze nasz, wyzbywamy się indywidualizmu: „Zaimek «nasz» rozpoczynający Modlitwę Pańską, podobnie jak «my» czterech ostatnich próśb, nie wyklucza nikogo. Aby był on wypowiadany w prawdzie (por. Mt 5, 23-24; 6, 14-16), należy przezwyciężyć nasze podziały i różnice"30. Ponieważ miłość Boga do ludzi nie zna granic, również taka sama powinna być chrześcijańska modlitwa i postawa wobec ludzi. Katechizm Kościoła

24 Nadzieja zbawienia dla dzieci. Nota wstępna; por. Katechizm Kościoła katolickiego, 1261 [dalej: KKK].

\footnotetext{
$25 \quad$ KKK 1257.

26 Por. Kongregacja Nauki Wiary, dekl. Dominus Iesus, 20.

27 Kongregacja Nauki Wiary, dekl. Dominus Iesus, 22.

28 Por. Kongregacja Nauki Wiary, dekl. Dominus Iesus, 20.

29 Por. Kongregacja Nauki Wiary, dekl. Dominus Iesus, 21.

$30 \quad$ KKK 2792.
} 
katolickiego zachęca, aby „modlić się ze wszystkimi i za wszystkich ludzi, którzy Go jeszcze nie znają, aby wszyscy byli «zgromadzeni w jedno» (J 11, 52). Ta Boża troska o wszystkich ludzi i o całe stworzenie ożywiała wszystkich wielkich ludzi modlitwy; powinna ona napełnić naszą modlitwę wszechogarniającą miłością, gdy ośmielamy się mówić: Ojcze «nasz»" ${ }^{31}$. Tak więc w głoszeniu Chrystusowego orędzia nie ma miejsca na świadomy ekskluzywizm.

Trzeba jednak zauważyć, że wolność człowieka zakłada możliwość samowykluczenia ze wspólnoty zbawionych. Na przykład w odniesieniu do debatowanej współcześnie kwestii związków niesakramentalnych Jan Paweł II uważał, że tak zwane „wolne związki” znieważają godność małżeństwa oraz że „akt płciowy powinien mieć miejsce wyłącznie w małżeństwie; poza nim stanowi zawsze grzech ciężki i wyklucza z Komunii sakramentalnej" ${ }^{\prime 2}$. Gdy samowykluczenie ma charakter ostateczny, mamy do czynienia z rzeczywistością piekła: „Umrzeć w grzechu śmiertelnym, nie żałując za niego i nie przyjmując miłosiernej miłości Boga, oznacza pozostać $\mathrm{z}$ wolnego wyboru na zawsze oddzielonym od Niego. Ten stan ostatecznego s a mo w yk lu c ze n ia z jedności z Bogiem i świętymi określa się słowem "piekło»" ${ }^{33}$.

\section{Wykluczenie nieświadome - brak wyobraźni miłosierdzia}

Może się zdarzyć, że w posłudze słowa dojdzie do nieświadomego wykluczenia. Taka sytuacja ma miejsce wówczas, gdy regularnie pomijane są sprawy niektórych grup ludzi. Gdy na przykład przytaczane są jedynie obrazy i przykłady z życia mężczyzn. Znamię ekskluzywności i nieświadomego czy podświadomego wykluczenia nosi lekceważący stosunek do przedstawicieli innych ras, wyznań i religii, co oczywiście nie wyklucza wolności do osobistych przekonań i krytycznej oceny.

\footnotetext{
31 KKK 2793.

32 Jan Paweł II, adhort. apost. Familiaris consortio, 81; KKK 2390.

33 KKK 1033.
} 
Wskutek wzrastającej wrażliwości społecznej i badań nad „językiem inkluzywnym” wyeliminowane zostały takie terminy jak „Murzyn” jako rodzące pejoratywne skojarzenia określenie rasistowskie oraz „eskimos”, czyli „zjadacz surowego mięsa”. Substytutem pierwszego terminu jest na przykład „Afroamerykanin” czy „Afroeuropejczyk”, a drugiego „inuita”. Bardziej subtelny ekskluzywizm ma miejsce w przypadku stosowania kwantyfikatorów wyłącznie w odmianie męskiej: „każdy”, „niektóry”, gdy należałoby zastosować również odmiany żeńskie tych określeń. W wersji inkluzywnej zatem należałoby stwierdzić „każdy i każda". Rosnąca w Kościele w ostatnich latach świadomość potrzeby stosowania języka inkluzywnego znalazła wyraz, zwłaszcza pod koniec pontyfikatu Jana Pawła II, w homiliach papieskich i dokumentach Kościoła. Termin „człowiek” uzupełniano dookreśleniem: „mężczyzna i kobieta" ${ }^{34}$. Przykładów dostarcza wydany przez Kongregację Nauki Wiary List do biskupów Kościoła katolickiego o współdziałaniu mężczyzny i kobiety w kościele i świecie (31.05.2004). Znajdujemy w nim sformułowania: „ze wszystkimi ludźmi, mężczyznami i kobietami” ${ }^{35}$; „sytuacja człowieka, mężczyzny i kobiety, stworzonych na obraz Boga, jest jedna i niepodzielna" ${ }^{36} ;$, [...] objawienia ludzkości, mężczyznom i kobietom. [...] w każdym mężczyźnie i w każdej kobiecie" ${ }^{37}$.

34 Jan Paweł II dał wyraz swej wrażliwości w omawianej kwestii już w liście apostolskim Mulieris dignitatem (15.08.1988): „Człowiek jest osobą, w równej mierze mężczyzną i kobietą: oboje wszakże zostali stworzeni na obraz i podobieństwo Boga osobowego” (nr 6); „Na zasadzie wzajemnego bycia «dla» drugiego, w «komunii» osób, rozwija się w tych dziejach zamierzona przez Stwórcę integracja w samym człowieczeństwie (całej ludzkości) tego, co «męskie» i tego, co «kobiece»" (nr 7).

35 Kongregacja Nauki Wiary, List do biskupów Kościoła katolickiego o współdziałaniu mężczyzny i kobiety $w$ kościele $i$ świecie, 1.

36 Kongregacja Nauki Wiary, List do biskupów Kościoła katolickiego..., dz. cyt., 14.

37 Kongregacja Nauki Wiary, List do biskupów Kościoła katolickiego..., dz. cyt., 17. To zróżnicowanie jest ontologiczne, dotyczy nie tylko życia doczesnego, ale i określa człowieka przez całą wieczność: „Męskość i żeńskość są objawione jako przynależne ontologicznie stworzeniu i dlatego też są przeznaczone, aby trwać poza czasem teraźniejszym, oczywiście w przemienionej formie. W ten sposób cechują one miłość, która «nigdy nie ustaje» (1 Kor 13, 8), choć zostanie zatracony wyraz czasowy i ziemski płciowości, przystosowany do życia znaczonego zradzaniem i śmiercią. [...] Zróżnicowani od początku stworzenia i pozostający takimi na całą wieczność, mężczyzna i kobieta włączeni w misterium paschalne Chrystusa nie postrzegają więc już więcej różnic jako motywu ich niezgody, które trzeba 
W przepowiadaniu należy brać pod uwagę wrażliwość słuchaczy. Papież Franciszek zwraca uwagę na potrzebę uwzględnienia zasady komunikacji społecznej, według której ważne jest nie tylko to, co jest wypowiadane, ale przede wszystkim to, co jest słyszane. Słuchacze mają różnorodne doświadczenia życiowe, percepcję i wrażliwość. Im lepiej kaznodzieja wsłuchuje się w to, co mają do powiedzenia inni, tym większa jest szansa, że sam zostanie wysłuchany. "Największym zagrożeniem dla kaznodziei jest przyzwyczajenie się do swojego języka i uważanie, że wszyscy inni spontanicznie się nim posługują i rozumieją go. Jeśli chcemy się dostosować do języka innych ludzi, by możliwe było dotarcie do nich ze Słowem, trzeba wiele słuchać, trzeba dzielić życie z ludźmi i bacznie zwracać na nich uwage" ${ }^{38}$.

Papież Franciszek, odrzucając zdecydowanie jakiekolwiek wykluczenie społeczne człowieka, daje temu wyraz nie tyle przez stosowanie języka inkluzywnego, ile raczej symboliczne gesty i zachowania. Papież nie wzdryga się przed przytuleniem ludzi zniekształconych przez choroby. Wiedząc, że bezdomnym w Rzymie brakuje nie tyle jedzenia, ile możliwości umycia się, udostępnił krużganki watykańskie na łaźnię dla nich. Jałmużnika watykańskiego bpa Konrada Krajewskiego włączył do kolegium kardynalskiego i uczynił jednym z najbardziej rozpoznawalnych wśród swoich najbliższych współpracowników. Odbywa wizyty apostolskie do miejsc, w których naruszane są prawa człowieka, czemu dał przykład, udając się do Mjanmy (dawniej Birmy, 26-30.11.2017) w czasie tragicznej sytuacji ludu Rohingya. Upomina się o los uchodźców i migrantów, czego wyrazem była jego pierwsza wizyta apostolska 8 lipca 2013 roku na wyspie Lampedusa ${ }^{39}$.

Zadaniem duszpasterzy i głosicieli słowa Bożego jest upominanie się o prawa i godność osób pozbawionych głosu. Taki apel może poruszyć

przezwyciężyć poprzez ich negację albo przez ich spłycenie, ale jako możliwości współdziałania, o które należy się troszczyć we wzajemnym poszanowaniu odrębności” - Kongregacja Nauki Wiary, List do biskupów Kościoła katolickiego..., dz. cyt., 12.

38 Franciszek, adhort. apost. Evangelii gaudium, 158.

39 Zob. H. Sławiński, Wkład papieża Franciszka w język nowej ewangelizacji, w: Nowa ewangelizacja. Język - teologia - kultura, red. M. Nowak, W. Przyczyna (Teolingwistyka 13), Tarnów 2017, s. 249-251. 
słuchaczy, którzy podejmą możliwe dla siebie inicjatywy, by poprawić los osób wykluczonych.

Przeobrażenia społeczne niosące ze sobą rosnącą świadomość godności człowieka, mężczyzny i kobiety, dziecka, dorosłego i seniora, a przy tym wrażliwość na dobór języka - wszystko to stanowi wyzwanie dla głosicieli słowa Bożego do troski o odpowiedni dobór słów i stylu wypowiedzi. Należy okazywać szacunek wobec ludzi przynależących do różnych grup etnicznych i rasowych, reprezentujących różne religie, kultury i klasy ekonomiczne. Należy uszanować odmienną płeć, wiek, zawód, poglądy polityczne i status społeczny. To, co ludzi łączy, znaczy więcej niż to, co różnicuje. Bardzo wymowne są słowa św. Pawła, który pisząc do Galatów, podkreślił, że zbawcze dzieło dokonane przez Chrystusa za wszystkich zaowocowało pojednaniem ludzi między sobą: „Nie ma już Żyda ani poganina, nie ma już niewolnika ani człowieka wolnego, nie ma już mężczyzny ani kobiety, wszyscy bowiem jesteście kimś jednym w Chrystusie Jezusie" (Ga 3,28). Stwierdzenie to nie neguje różnic między ludźmi. Oznacza raczej to, że wszelka wrogość, przemoc i rywalizacja, które wynaturzają międzyludzkie relacje, zostały przez Chrystusa przezwyciężone. „Nie ma więc w Chrystusie i w Kościele żadnej nierówności ze względu na rasę albo przynależność narodową, stan społeczny albo płeć" ${ }^{40}$. Toteż głosiciel słowa Bożego musi nieustannie pielęgnować zdolność do empatii, okazywać szacunek każdej osobie ludzkiej i wyrażać ów szacunek także w języku homilii, kazań i konferencji ${ }^{41}$.

\section{Głoszenie osoby i orędzia Jezusa, który utożsamił się z wykluczonymi}

Centrum przepowiadania chrześcijańskiego jest osoba i orędzie Jezusa Chrystusa ${ }^{42}$. On zaś dobrowolnie dał się wykluczyć. Albowiem,

$40 \quad$ II Sobór Watykański, konst. Lumen gentium, 32; por. 1.

${ }_{41}$ Por. H. Sławiński, Między ciągłością a zmianą. Teoria homilii w Stanach Zjednoczonych po II Soborze Watykańskim, Kraków 2008, s. 139-140.

42 Por. Benedykt XVI, adhort. apost. Verbum domini, 59. 
jak napisał do Galatów św. Paweł: „Przeklęty każdy, którego powieszono na drzewie" (Ga 3,13). Owa zgoda Jezusa na bycie wykluczonym była ceną za zbawienie wszystkich wykluczonych. Jezus został ukrzyżowany extra muros - poza murami miasta (por. Hbr 13, 12n), poza winnicą, poza wspólnotą Izraela (por. Łk 20,15), poza świętym miastem. W ten sposób objawił, że miłość Boża może być doświadczona dokładnie tam, gdzie w oczach ludzi nie ma Bogat.

Do Jezusa można odnieść słowa proroka Izajasza o Słudze Jahwe zaliczonym do bezbożnych (por. Iz 53, 12). Młody Kościół był przekonany, że Ukrzyżowany ujmuje się za każdym człowiekiem, za najsłabszymi, najbardziej zdesperowanymi, za wykluczonymi. Święty Paweł, podobnie jak pierwotna wspólnota chrześcijańska, miał żywą świadomość, że krzyż Jezusa został postawiony pośrodku grzesznego świata ${ }^{44}$.

Owa świadomość dochodzi do głosu także współcześnie w nauczaniu niektórych biskupów. W jednej z konferencji głoszonych podczas rekolekcji watykańskich dla Jana Pawła II i Kurii Rzymskiej w dniach 12-18 marca 2000 roku wietnamski arcybiskup Francis Xavier Nguyen Van Thuan (1928-2002) opowiadał o swoim odkryciu. 15 sierpnia 1975 roku o godzinie 14. kilka miesięcy po nominacji na biskupa koadiutora stolicy Wietnamu został aresztowany w Sajgonie (Ho Chi Minh). W czasie wspomnianych rekolekcji wyznał, że Jezus ukrzyżowany poza murami Jerozolimy uświadomił mu, że musi zaangażować się w nową formę ewangelizacji. Nie mógł już działać jako biskup diecezji, ale jak misjonarz extra muros, ad extra, wychodząc do wszystkich ${ }^{45}$. Extra muros, ad extra wyjście poza mury miasta, na zewnątrz to wyjście poza mury kościoła,

43 Por. F.X. Nguyen Van Thuan, Testimony of Hope. The Spiritual Exercises of John Paul II, dz. cyt., s. 77-78.

${ }_{44}$ Por. F.X. Nguyen Van Thuan, Testimony of Hope. The Spiritual Exercises of John Paul II, dz. cyt., s. 78.

45 "Upon my departure from Saigon, Jesus, crucified outside the walls of Jerusalem, made me understand that I had to engage in a new form of evangelization. I no longer acted as a bishop within a diocese, but extra muros, as a missionary ad extra, ad vitam, ad summum going outside, for all my life, to the very limits of my capacity to love and give of myself. Now, yet another dimension opened itself, ad omnes - for all. [...] My prison was divine providence. It was the will of God" - F. X. Nguyen Van Thuan, Testimony of Hope. The Spiritual Exercises of John Paul II, dz. cyt., s. 79. 
poza świętą liturgię, do ludzi żyjących w grzechu, gdzie pozornie nie ma Boga; to wyjście do wykluczonych z życia sakramentalnego. Słowo Boże jest dla wszystkich. Można i należy je głosić wszystkim, a uprzywilejowanymi adresatami orędzia zbawienia są ubodzy, wykluczeni.

Papież Franciszek jest kontynuatorem tego myślenia. Podkreśla konieczność przejścia od duszpasterstwa zachowawczego do duszpasterstwa zdecydowanie misyjnego ${ }^{46}$. Zachęca do nawrócenia misyjnego ${ }^{47}$, do kreatywności misyjnej ze strony duszpasterzy i wiernych świeckich przynależących do wspólnot parafialnych ${ }^{48}$. Przestrzega jednocześnie, że brak troski o poprawę losu wykluczonych prowadzi do rozkładu wspólnot chrześcijańskich:

„Każda wspólnota Kościoła, która nie zamierza w pełni i w sposób twórczy skutecznie współpracować, aby ubodzy żyli godnie i nikt nie był wykluczony, narazi się także na ryzyko rozkładu, chociaż mówi o tematach społecznych lub krytykuje rządy. Łatwo podda się w końcu światowości duchowej, maskowanej praktykami religijnymi, bezowocnymi zebraniami lub pustymi przemówieniami"49.

Piętnując niewolniczą mentalność indywidualistyczną, obojętność i egoizm, Franciszek dostrzega konieczność bycia blisko bezdomnych, narkomanów, uchodźców, migrantów, ludów tubylczych, samotnych i opuszczonych osób w podeszłym wieku. Papież zachęca, by właśnie w takich osobach rozpoznawać cierpiącego Chrystusa i wyznaje: ,jestem pasterzem Kościoła bez granic, który czuje się matką wszystkich"50.

Jak skandalem dla słuchaczy Jezusa w synagodze nazaretańskiej było Jego orędzie o ofercie zbawienia obejmującej także pogan, tak też skandalem dla niektórych jest powiedzenie zdeklarowanemu homoseksualiście, że Bóg go kocha takim, jakim jest. Trzeba oczywiście zawsze wyraźnie odróżnić grzech od grzesznika i dopowiedzieć, że głoszenie zbawienia grzesznikom nie oznacza akceptacji dla ich grzechów. Głoszenie pełnej Ewangelii obejmuje również słowa „Idź, a od tej chwili już nie grzesz!”

\footnotetext{
Por. Franciszek, adhort. apost. Evangelii gaudium, 15.

7 Por. Franciszek, adhort. apost. Evangelii gaudium, 25, 30.

48 Por. Franciszek, adhort. apost. Evangelii gaudium, 28.

49 Franciszek, adhort. apost. Evangelii gaudium, 207.

50 Por. Franciszek, adhort. apost. Evangelii gaudium, 208, 210.
} 
(J 8, 11). Ale zasadniczy akcent w głoszeniu Dobrej Nowiny nie jest kładziony na grzech, ale na miłość Boga do grzesznych ludzi. „Nie potrzebują lekarza zdrowi, lecz ci, którzy się źle mają" (Mt 9, 12). Jezus oświadczył: „Nie przyszedłem, aby powołać sprawiedliwych, ale grzeszników" (Mk 2, 17; por. Łk 5, 32; 1 Tm 1, 15). Powiedział także, że wielka jest w niebie „radość z jednego grzesznika, który się nawraca” (Łk 15, 7).

Jezus świadomie utrzymywał kontakty z osobami uznawanymi wówczas za wykluczonych społecznie, z celnikami i publicznymi grzesznikami (por. Mk 2, 14-17), za co był podejrzewany przez nieprzychylnie nastawionych ludzie o opętanie (por. Mk 3, 22; J 8, 48; 10, 20; KKK 574).

„Jezus gorszył przede wszystkim przez to, że utożsamił swoje miłosierne postępowanie wobec grzeszników z postawą samego Boga wobec nich (por. Mt 9, 13; Oz 6, 6). Dał nawet do zrozumienia, że zasiadając do stołu z grzesznikami (por. Łk 15,1-2), dopuszcza ich do uczty mesjańskiej (por. Łk 15, 23-32)"51.

Czyż głosiciel Ewangelii mógłby powiedzieć, że Bóg jest miłością i kocha wszystkich ludzi z wyjątkiem rozwodników, ateistów czy agnostyków? Nie! Sednem ewangelicznego orędzia jest właśnie to, że Bóg kocha wszystkich, zwłaszcza tych, którzy się źle mają, kocha grzeszników. Przecież to jest nauczanie Kościoła (por. KKK 2357-2359) od czasów apostolskich, od orędzia przekazanego przez umiłowanego ucznia Jezusa: „W tym przejawia się miłość, że nie my umiłowaliśmy Boga, ale że On sam nas umiłował i posłał Syna swojego jako ofiarę przebłagalną za nasze grzechy” (1 J 4, 10; por. $1 \mathrm{~J} 4$ 4, 19). Ponieważ „Chrystus umarł za nas, gdyśmy byli jeszcze grzesznikami” (Rz 5, 8), również dzisiaj Jego Dobra Nowina adresowana jest do grzeszników, do wykluczonych. Oni są jej uprzywilejowanymi adresatami.

$51 \quad$ KKK 589. 


\section{Od wykluczenia do integracji eklezjalnej i misji - przykład kształtowania wyobraźni miłosierdzia}

Jest w Ewangelii scena opisująca pedagogię Jezusa wobec osoby wykluczonej. Był nią niewidomy żebrak, Bartymeusz z Jerycha. Chciał spotkać Jezusa i doświadczyć na sobie Jego mocy, o której słyszał od innych. Wołał więc niestrudzenie: „Jezusie, Synu Dawida, ulituj się nade mną!” (Mk 10, 47). Bartymeusz był niepełnosprawny fizycznie, jako niewidomy nie mógł czytać Prawa żydowskiego, przez co łatwo było go zaliczyć do kategorii grzeszników. Ponadto nie mógł pracować i skazany był na żebranie o datki. Tym jednak, co miał, była głęboka wiara w Jezusa i niezłomna nadzieja na uzdrowienie. Tłumy ludzi, które szły za Jezusem, traktowały Bartymeusza jako wykluczonego. Tłumy te widziały Jezusa, celebrytę, ale eliminowały Bartymeusza, nie chciały na niego patrzeć ani go słuchać. Gdy wołał za Jezusem, błagając o miłosierdzie dla siebie, „wielu nastawało na niego, żeby umilkł” (Mk 10, 48).

Ludzie podążający za Jezusem byli nie tylko obojętni na człowieka niepełnosprawnego i biednego, ale wręcz nieprzychylni. Nie dość, że nie wsparli go żadnym datkiem, to jeszcze uciszali go, wykluczyli go. Usiłowali zgasić jego nadzieję. Dla nich ważne było tylko to, że oni widzieli Jezusa. Widzieli fizycznie, ale byli ślepi duchowo, brakowało im odrobiny empatii, wrażliwości społecznej. Jezus okazał się uzdrowicielem zarówno Bartymeusza, jak i tych, którzy tworzyli tłum. Usłyszał wołanie Bartymeusza. Wiedział też, że uzdrowienia, choć innego, potrzebowali zapatrzeni w siebie ludzie z tłumu podążającego za Nim. Najpierw uzdrowił ich, wzbudzając w nich empatię, zainteresowanie wykluczonym, niewidomym żebrakiem; ,przystanął i rzekł: «Zawołajcie go!»” (Mk 10, 49). Mógł wszakże sam podejść do Bartymeusza bądź zawołać: „Podejdź tutaj". Celowo tego nie zrobił. Poruszył ludzi z tłumu, żeby oni sami dostrzegli niepełnosprawnego człowieka, którego skazano na wykluczenie społeczne. Skłonił ich do porzucenia zniewalającego indywidualizmu i obojętności. Uzdrowił ich ślepotę społeczną. To jest niepełnosprawność groźniejsza od niepełnosprawności fizycznej. Cud się dokonał. Ludzie z tłumu początkowo nieprzychylni Bartymeuszowi zmienili swoją postawę wobec niego pod wpływem słowa Jezusa: „,przywołali niewidomego, 
mówiąc: «Bądź dobrej myśli, wstań, woła cię»" (Mk 10, 49). Stali się zwiastunami pocieszenia i Dobrej Nowiny, włączyli go do swojego grona i razem przyszli do Jezusa. Obojętny, nieczuły tłum pod wpływem słowa Jezusa przeobraził się we wspólnotę wrażliwą na wykluczonego człowieka. Wówczas Jezus uzdrowił także Bartymeusza, mówiąc: „«Idź, twoja wiara cię uzdrowiła». Natychmiast przejrzał i szedł za Nim drogą" (Mk 10, 52). Uzdrowiony Bartymeusz został wydobyty z izolacji, na którą został skazany ze względu na niepełnosprawność i ubóstwo; poszedł wraz z innymi za Jezusem, stał się uczestnikiem Jego drogi (por. Mk 10, 52$)^{52}$.

Ewangeliczna historia stanowi uniwersalną Dobrą Nowinę dla każdego pokolenia słuchaczy. Na jej kanwie można uwrażliwiać słuchaczy na sytuację ludzi wykluczonych. Najpierw trzeba otworzyć oczy i dostrzec wykluczonych, a potem potraktować ich jako część społeczeństwa. To już wiele. Społeczeństwo przemienia się, gdy porzuca inercję, by poprawić los najuboższych, wykluczonych.

Jedna z homilii rozwijająca historię uzdrowienia Bartymeusza i tłumów przez Jezusa została opatrzona aktualizującą refleksją: „W dramacie z 1919 roku pod tytułem Ojciec upokorzony Paula Claudela (1868-1955) urodziwa, ale niewidoma dziewczynka żydowskiego pochodzenia pyta swojego widzącego przyjaciela chrześcijanina: «Wy, którzy widzicie, jaki użytek zrobiliście ze światła?»" 53 .

Przepowiadanie słowa Bożego, zwłaszcza podczas liturgii, w postaci homilii „uaktualnia przesłanie Pisma Świętego, ażeby wierni mogli odkryć obecność i skuteczność słowa Bożego w swoim codziennym życiu. Powinna ona ułatwić zrozumienie sprawowanej tajemnicy, zachęcić do misji, przygotowując zgromadzenie do wyznania wiary, modlitwy powszechnej i liturgii eucharystycznej" ${ }^{54}$. Uważne słuchanie słowa Bożego i pełny udział w tajemnicy Eucharystii uzdalnia i motywuje do misji. Według Jana Pawła II komunia „w samej swej istocie przyjmuje kształt

52 Por. H. Sławiński, 30 niedziela zwykła, w: Słowo na niedzielę. Rok liturgiczny B, Kraków 2014, s. 257-258; por. R. Hajduk, Leczyć rany serc złamanych. Przyczynek do kaznodziejstwa terapeutycznego, Kraków 1996, s. 32-33.

53 H. Sławiński, 30 niedziela zwykła, dz. cyt., s. 259.

54 Benedykt XVI, adhort. apost. Verbum Domini, 59. 
komunii misyjnej”55. Przypominając te słowa, Dyrektorium homiletyczne przytacza także misyjny apel Franciszka o potrzebie głoszenia Ewangelii „wszystkim ludziom, w każdym miejscu, przy każdej okazji, nie zwlekając, bez niechęci i bez obaw. Radość Ewangelii jest dla całego ludu, nie może z udziału w niej wykluczać nikogo" ${ }^{56}$.

\section{Zakończenie}

Przychodząc na świat, by odkupić człowieka, Chrystus Pan nie rozwiązał problemów społecznych. A jednak Jego życie i nauczanie jest przełomowe w historii ludzkości. Dokonał on rewaluacji człowieka. W Jego oczach najcenniejsi są Ci, którzy potrzebują pomocy. Bóg bowiem „strąca władców z tronu, a wywyższa pokornych" (Łk 1, 52). Ucząc się od swojego Mistrza, Kościół kieruje się w pracy duszpasterskiej opcją na rzecz ubogich. Również głoszenie Ewangelii, wierne Nauczycielowi z Nazaretu, zawiera w sobie Dobrą Nowinę dla tych, „którzy się źle mają” (Mt 9, 12). Ponieważ, jak uczy aktualny papież, we współczesnym świecie problemem ludzi ubogich stało się wykluczenie, należy mówić o preferencyjnej opcji na rzecz wykluczonych oraz podejmować inicjatywy duszpasterskie, które pomogą przezwyciężyć zarówno wykluczenie społeczne, jak i samowykluczenie się człowieka ze wspólnoty wiary i w ogóle ze społeczeństwa. Należy podkreślać, że w społeczeństwie nie ma nikogo, kto byłby niepotrzebny. Dobra Nowina o Bogu Ojcu, który kocha wszystkich ludzi, bez jakiejkolwiek różnicy, o Jezusie Chrystusie, który zbawił wszystkich, oraz o równej godności każdego człowieka stanowi silną podstawę do przeobrażenia świata zgodnie z zamysłem Bożym.

55 Jan Paweł II, adhort. apost. Christifideles laici, 32.

56 Franciszek, adhort. apost. Evangelii gaudium, 23; Kongregacja ds. Kultu Bożego i Dyscypliny Sakramentów, Dyrektorium homiletyczne, 36. 


\section{Summary}

\section{Problem wykluczenia społecznego w kościelnej posłudze słowa}

Problemem społecznym, na który szczególnie zwraca uwagę papież Franciszek, jest wykluczenie społeczne. Nie chodzi w tym nowym zjawisku o wykorzystywanie ludzi, ale o całkowite odrzucenie; powiedzenie komuś, że jest do niczego niepotrzebny. Takie traktowanie człowieka jest całkowicie sprzeczne z Dobrą Nowiną Jezusa Chrystusa, który wyklucza „wykluczenie świadome” kogokolwiek. Artykuł podejmuje tę kwestię, a także omawia „wykluczenie nieświadome”, które wynika z zastosowania języka, który nie jest wystarczająco inkluzywny. Zadaniem głosicieli słowa Bożego jest podejmować problem wykluczenia i ukazywać, że Jezus utożsamił się z wykluczonymi. Ewangelia dostarcza przykładu przeobrażenia społecznego wskutek interwencji Jezusa. Historia niewidomego żebraka Bartymeusza z Jerycha jest paradygmatem dla przepowiadania na rzecz integracji wykluczonych.

Słowa kluczowe: wykluczeni, przepowiadanie, Bartymeusz, społeczne nauczanie Kościoła

\section{The Problem of Social Exclusion in the Church's Preaching}

The social problem that Pope Francis particularly points out is social exclusion. It describes not simply the exploitation and oppression of other people. Exclusion means the treatment of the people even worse as the society's fringes, underside or disenfranchised, but as no longer even a part of it. The excluded are the outcast, totally rejected, the "leftovers", not needed in the society. Such treatment of a human person is completely contrary to the Good News of Jesus Christ, which excludes any "conscious exclusion" of anyone. The article addresses this issue and also discusses "unconscious exclusion" that results from the use of a language that is not sufficiently inclusive. The duty of the preachers of the word of God is to discuss the problem of exclusion and point out to Jesus, who identified himself with the excluded. The Gospel provides an example of social transformation as a result of Jesus' intervention. The story of the blind beggar Bartimaeus of Jericho is a paradigm for preaching for the integration of the excluded.

Keywords: excluded, preaching, Bartimaeus, social teaching of the Church

\section{Bibliografia}

Anderson K. E., Bacik J. J., A Light Unto My Path. Crafting Effective Homilies, New York-Mahwah, NJ 2006. 
Benedykt XVI, Adhortacja apostolska Verbum Domini (30.09.2010), Kraków 2010.

Dziedzic J., Kościół wobec starości. Perspektywa pastoralnoteologiczna, „Polonia Sacra” 19 (2015) nr 1 (38), s. 95-113.

Encyklopedia katolicka, t. 20, red. E. Gigilewicz, Lublin 2014.

Encyklopedia nauczania społecznego Jana Pawła II, red. A. Zwoliński, Radom 2003.

Franciszek, Adhortacja apostolska Evangelii gaudium (24.11.2013), Kraków 2013.

Franciszek, Audiencja ogólna. Pilnie potrzebna ekologia (05.06.2013), http://info.wiara.pl/doc/1584356.Pilnie-potrzebna-ekologia (27.04.2018).

Franciszek, Orędzie na I Światowy Dzień Ubogich (33 niedziela zwykła w ciągu roku), 19 listopada 2017. Nie miłujmy słowem, ale czynem (13.06.2017), http:// w2.vatican.va/content/francesco/pl/messages/poveri/documents/papa-francesco_20170613_messaggio-i-giornatamondiale-poveri-2017.html (27.04.2018).

Hajduk R., Leczyć rany serc złamanych. Przyczynek do kaznodziejstwa terapeutycznego, Kraków 1996.

Himes K. R., Odpowiedzi na 101 pytań o katolicką naukę społeczną, przekł. K. Biel, Kraków 2005.

Jan Paweł II, Adhortacja apostolska Familiaris consortio (22.11.1981), w: Adhortacje ojca świętego Jana Pawła II, t. 1, Kraków 1996, s. 65-160.

Jan Paweł II, Encyklika Sollicitudo rei socialis (30 grudnia 1987), Pallottinum, Poznań 1988.

Jan Paweł II, Katechizm Kościoła katolickiego (11.10.1992), Poznań 1994.

Jan Paweł II, List apostolski Mulieris dignitatem (15.08.1988), w: Wybór listów ojca świętego Jana Pawła II, t. 1, Kraków 1997, S. 80-141.

Jan Paweł II, Adhortacja apostolska Christifideles laici (30.12.1988), w: Adhortacje ojca świętego Jana Pawła II, t. 1, Kraków 1996, s. 269-377.

Kodeks prawa kanonicznego, Poznań 1983.

Kongregacja ds. Biskupów, Dyrektorium o pasterskiej posłudze biskupów, Apostolorum Successores (22 lutego 2004).

Kongregacja ds. Kultu Bożego i Dyscypliny Sakramentów, Dyrektorium homiletyczne (29.06.2014), Poznań 2015.

Kongregacja Kultu Bożego i Dyscypliny Sakramentów, Nowe ogólne wprowadzenie do Mszału rzymskiego. Z trzeciego wydania Mszału rzymskiego (18.03.2002), Poznań 2004.

Kongregacja Nauki Wiary, Deklaracja Dominus Iesus (6.08.2000), https://opoka.org. $\mathrm{pl} /$ biblioteka/W/WR/kongregacje/kdwiary/dominus_iesus.html (27.04.2018).

Kongregacja Nauki Wiary, List do biskupów Kościoła katolickiego o współdziałaniu mężczyzny $i$ kobiety w kościele $i$ świecie (31.07.2004), https://opoka.org.pl/biblioteka/W/ WR/kongregacje/kdwiary/kobieta_31052004.html (27.04.2018).

Leksykon teologii pastoralnej, red. R. Kamiński, W. Przygoda, M. Fiałkowski, Lublin 2006.

Międzynarodowa Komisja Teologiczna, Nadzieja zbawienia dla dzieci, które umieraja bez chrztu (19.01. 2007), tłum. J. Królikowski, Poznań 2008.

O'Collins G., Farrugia E. G., Leksykon pojęć teologicznych $i$ kościelnych $z$ indeksem angielsko-polskim, przekł. J. Ożóg, B. Żak, Kraków 2002. 


\section{ks. Henryk Sławiński}

Papieska Rada Iustitia et Pax, Kompendium nauki społecznej Kościoła (Cittá del Vaticano 2004), przekł. D. Chodyniecki, A. Dalach, J. Nowak, Kielce 2005.

Papież: Zepsuty komputer - tragedia. Dramat osób - normalność, http://info.wiara. $\mathrm{pl} /$ doc/1584238.Papiez-Zepsuty-komputer-tragedia-Dramat-osob-normalnosc (27.04.2018).

Sławiński H., Między ciągtościa a zmiana. Teoria homilii w Stanach Zjednoczonych po II Soborze Watykańskim, Kraków 2008.

Sławiński H., Preferencyjna miłość do ubogich w przepowiadaniu Kościoła, „Analecta Cracoviensia" 49 (2017), s. 163-174.

Sławiński H., Słowo na niedzielę. Rok liturgiczny B, Kraków 2014.

Sławiński H., Troska Kościoła o poprawę jakości homilii: od synodu o Eucharystii i Sacramentum Caritatis do synodu o stowie Bożym $i$ Verbum Domini, „Colloquia Theologica Ottoniana" 1 (2012), s. 37-62.

Sławiński H., Wkład papieża Franciszka w język nowej ewangelizacji, w: Nowa ewangelizacja. Język - teologia - kultura, red. M. Nowak, W. Przyczyna, Tarnów 2017 (Teolingwistyka, 13), s. 231-255.

Słownikjęzyka polskiego, t. 3, red. H. Szkiłądź i in., Warszawa 1985.

Sobór Watykański II, Deklaracja o wolności religijnej Dignitatis humanae (9.12.1965), w: Sobór Watykański II. Konstytucje, dekrety, deklaracje. Tekst polski. nowe tłumaczenie, Poznań 2002, s. 410-421

Sobór Watykański II, Dekret o działalności misyjnej Kościoła Ad gentes (7.12.1965), w: Sobór Watykański II. Konstytucje, dekrety, deklaracje. Tekst polski. nowe tlumaczenie, Poznań 2002, s. 433-471.

Sobór Watykański II, Konstytucja dogmatyczna o Kościele Lumen gentium (4.12.1963), w: Sobór Watykański II. Konstytucje, dekrety, deklaracje. Tekst polski. nowe tłumaczenie, Poznań 2002, s. 104-186.

Van Thuan F. X. N., Testimony of Hope. The Spiritual Exercises of John Paul II, Boston 2000.

Waznak R. P., An Introduction to the Homily, Collegeville, MN 1998. 